Varicella-Zoster Virus 


\section{Contributions to Microbiology}

Vol. 3 


\title{
Varicella-Zoster Virus
}

Molecular Biology, Pathogenesis, and Clinical Aspects

\author{
Volume Editors Manfred H. Wolff, Witten \\ Stefan Schünemann, Witten \\ Axel Schmidt, Wuppertal
}

38 figures and 26 tables, 1999

KARGER $\begin{aligned} & \text { Basel·Freiburg } \cdot \text { Paris } \cdot \text { London } \cdot \text { New York } \\ & \text { New Delhi·Bangkok·Singapore } \cdot \text { Tokyo } \cdot \text { Sydney }\end{aligned}$ 


\title{
Contributions to Microbiology
}

formerly 'Concepts in Immunopathology' and

'Contributions to Microbiology and Immunology'

\section{(n)}

\section{Axel Schmidt}

PD Dr. med., FIBA, Bayer AG, Pharma Research Antiinfectives, Wuppertal; Institute of Microbiology and Virology, University Witten-Herdecke, Germany

\author{
Library of Congress Cataloging-in-Publication Data \\ Varicella-Zoster virus: molecular biology, pathogenesis, and clinical aspects / \\ volume editors, Manfred H. Wolff, Stefan Schünemann, Axel Schmidt. \\ (Contributions to microbiology; vol. 3) \\ Includes bibliographical references and indexes. (hardcover: alk. paper) \\ 1. Herpesvirus diseases. 2. Varicella-zoster virus. I. Wolff, Manfred H. II. Schünemann, Stefan. \\ III. Schmidt, Axel, 1962- . IV. Series. \\ [DNLM: 1. Herpes Zoster. 2. Herpesvirus 3. Human - pathogenicity. WC 575 V299 1999] \\ QR201.H48V37 1999 \\ $616.9^{\prime} 25-\mathrm{dc} 21$ \\ ISSN $1420-9519$ \\ ISBN 3-8055-6884-3
}

Bibliographic Indices. This publication is listed in bibliographic services, including Current Contents ${ }^{\circledR}$ and Index Medicus.

Drug Dosage. The authors and the publisher have exerted every effort to ensure that drug selection and dosage set forth in this text are in accord with current recommendations and practice at the time of publication. However, in view of ongoing research, changes in government regulations, and the constant flow of information relating to drug therapy and drug reactions, the reader is urged to check the package insert for each drug for any change in indications and dosage and for added warnings and precautions. This is particularly important when the recommended agent is a new and/or infrequently employed drug.

All rights reserved. No part of this publication may be translated into other languages, reproduced or utilized in any form or by any means electronic or mechanical, including photocopying, recording, microcopying, or by any information storage and retrieval system, without permission in writing from the publisher.

(c) Copyright 1999 by S. Karger AG, P.O. Box, CH-4009 Basel (Switzerland)

www.karger.com

Printed in Switzerland on acid-free paper by Reinhardt Druck, Basel

ISBN 3-8055-6884-3 


\section{Contents}

VII Preface

General Aspects

1 Morphological and Biological Characteristics of Varicella-Zoster Virus Rahaus, M.; Schünemann, S.; Wolff, M.H. (Witten)

10 Genomic Structure and Organization of Varicella-Zoster Virus Cohen, J.I. (Bethesda, Md.)

21 Overview of the Replication Cycle of Varicella-Zoster Virus Sadzot-Delvaux, C.; Baudoux, L.; Defechereux, P., Piette, J.; Rentier, B. (Liège)

43 Role of Glycoproteins in Varicella-Zoster Virus Infection Gershon, M.D.; Gershon, A.A. (New York, N.Y.)

61 Varicella-Zoster Virus: Latency and Reactivation Lungu, O.; Annunziato, P.W. (New York, N.Y.)

Pathogenesis and Clinical Aspects

76 Epidemiology of Varicella Infections Flisser, A.; Tapia-Conyer, R. (México)

86 Viremic Stages of Different Varicella-Zoster Virus-Associated Diseases Schünemann, S.; Wolff, M.H.; Rahaus, M. (Witten)

96 Chickenpox (Varicella)

Arvin, A.M. (Stanford, Calif.)

111 Shingles (Zoster)

Lilie, H.M.; Wassilew, S.W. (Krefeld) 
128 Postherpetic Neuralgia

Watson, C.P.N. (Toronto)

141 Infections during Pregnancy

Wutzler, P.; Sauerbrei, A. (Erfurt)

150 Diagnosis of Varicella-Zoster Virus-Associated Diseases with Special Emphasis on Infections in the Immunocompromised Host Wolff, M.H.; Schünemann, S.; Rahaus, M.; Schmidt, A. (Witten)

158 Approaches to the Treatment of Varicella-Zoster Virus Infections Whitley, R.J. (Birmingham, Ala.)

173 Experience with Live-Attenuated Varicella-Zoster Vaccines LaRussa, P. (New York, N.Y.)

193 Development of Recombinant Varicella-Zoster Virus Vaccines Arvin, A.M.; Mallory, S.; Moffat, J.F. (Stanford, Calif.)

201 Author Index

202 Subject Index 


\section{............................. \\ Preface}

The illnesses caused by herpesviruses in general and varicella-zoster virus (VZV) especially are known since antiquity. Despite being one of the first viruses to be visualized in the electron microscope by Ruska in 1943, it took quite a long time until Weller isolated it in 1953. Again, Weller and his coworkers discovered VZV to be the causative agent of both chickenpox and shingles by isolation of the virus from material of patients suffering from varicella and zoster. Since the discovery of this virus, which is one of the major human pathogens, knowledge about VZV accelerated rapidly. Our knowledge about clinical aspects, epidemiology, pathogenesis, and even latency and reactivation is extensive. Molecular studies started in 1972 when Ludwig isolated the genomic DNA of VZV. Since then, great steps have been taken concerning research of the biochemistry and molecular biology of the virus. To mention some highlights, the genome was sequenced by Davison, viral regulatory genes were identified by Straus and coworkers, and virus recombinants were constructed by Cohen and colleagues using cosmid technology. In addition, Takahashi and coworkers put great effort into the generation of an attenuated live VZV vaccine, which is nowadays licensed and has widespread use in developed countries.

Since the foundation of the Institute of Microbiology and Virology within the first private German university in Witten/Herdecke, our research group has been working on the problems of VZV. The pathogenesis of the virus is our main interest. We developed different PCRs as well as NASBA (nucleic acid sequence based amplification) to study the viremic phase at different stages of VZV-associated diseases. Lately, we have been focusing our efforts on the regulation of VZV glycoproteins as well. 
Our emphasis on VZV research and the fact that an up-to-date summarizing overview of the diverse problems concerning VZV is still missing, makes us very interested in a comprehensive book on this herpesvirus. Hence, we were happy and grateful when we were asked to start such a project. We were also very pleased that all the colleagues we asked to contribute to this edition spontaneously agreed to submit an article. All the chapters are written by international experts in the field and the editors sincerely wish to thank all of them for their excellent and efficient collaboration despite having other duties and responsibilities. Further, we would like to thank Mr. T. Nold and Mrs. R. Gisin from Karger for their kind assistance and excellent collaboration on this project.

Witten, Germany, May 1999

Manfred H. Wolff

Stefan Schünemann

Axel Schmidt 